\title{
SIFAT MEKANIK PAPAN PARTIKEL SEKAM PADI DENGAN RESIN POLYESTER TAK JENUH (YUKALLAC 157)
}

\author{
Sri Handani, Mega Ayu \\ Jurusan Fisika FMIPA Universitas Andalas \\ E-mail: shandani69@yahoo.com
}

\begin{abstract}
ABSTRAK
Telah dilakukan pengujian sifat mekanik untuk mengetahui kuat tekan dan kuat lentur papan partikel sekam padi dengan variasi resin 30\%, 40\%, 50\%, 60\%, 70\% dan $80 \%$. Papan dibuat dengan cetakan berukuran $5 \mathrm{~cm} \times 5 \mathrm{~cm} \times 6 \mathrm{~cm}$ untuk pengujian kuat tekan dan cetakan berukuran $10 \mathrm{~cm} \times 5 \mathrm{~cm} \times 3 \mathrm{~cm}$ untuk pengujian kuat lentur. Nilai kuat tekan maksimum diperoleh pada variasi resin $80 \%$ yaitu sebesar $9,2 \times 10^{7} \mathrm{~N} / \mathrm{m}^{2}$ dan nilai minimum pada variasi resin $30 \%$ yaitu sebesar $7,3 \times 10^{6} \mathrm{~N} / \mathrm{m}^{2}$. Papan partikel sekam padi yang memiliki nilai kuat lentur maksimum yaitu pada variasi resin $50 \%$ sebesar $4 \times 10^{7} \mathrm{~N} / \mathrm{m}^{2}$ dan nilai minimum pada variasi resin $30 \%$ sebesar $1,3 \times 10^{7}$ $\mathrm{N} / \mathrm{m}^{2}$.
\end{abstract}

Kata kunci : Sifat mekanik, kuat tekan, kuat lentur, resin, papan partikel sekam padi

\section{PENDAHULUAN}

Sekam padi merupakan bagian terluar dari butir padi yang merupakan hasil sampingan dari proses penggilingan padi. Sekitar $20 \%$ dari bobot padi adalah sekam padi dan kurang lebih $15 \%$ dari komposisi sekam adalah abu sekam yang selalu dihasilkan setiap kali sekam dibakar (Nuryono et all, 2003).

Selama ini sekam padi hanya dikenal sebagai limbah dan belum dimanfaatkan dengan baik, padahal sekam padi memiliki beberapa keunggulan seperti kemampuan menahan kelembaban, tidak mudah berjamur dan tidak berbau (Murdiyono, 2009). Sekam padi tidak mengandung bagian yang keras dan sulit dikerjakan, sekam padi juga tidak mengalami penyusutan, tidak mengerucut, tidak terpelintir, bengkok, terbelah atau melengkung. Sekam padi juga kuat, kaku, lurus dan ringan, serta memiliki harga yang jauh lebih murah daripada kayu gelondongan (Arbintarso, 2008).

Pemilihan sekam padi sebagai serat dalam pembuatan papan partikel karena sekam padi memenuhi syarat sebagai serat yang berbentuk bulir dan kemampuan ikat terhadap resin yang cukup tinggi, sehingga jika sekam padi dibuat papan partikel dengan resin sebagai pengikatnya akan dihasilkan papan partikel yang mempunyai kekuatan yang relatif baik (Arbintarso, 2008). Dalam penelitian ini akan diuji sifat mekanik papan partikel sekam padi dengan komposisi resin polyester tak jenuh (yucallac 157) yang divariasikan.

\section{METODE PENELITIAN}

Bahan-bahan yang digunakan adalah sekam padi dan resin yucallac 157 dengan katalis mekpo. Alat -alat yang digunakan adalah timbangan digital, blender, seperangkat alat uji kuat tekan dan kuat lentur, ayakan, cetakan terbuat dari seng, dan alat pengaduk dari kayu.

Sekam digiling sampai halus kemudian diayak menggunakan ayakan berukuran $2 \mathrm{~mm}$ untuk mendapatkan partikel sekam yang seragam dengan ukuran $2 \mathrm{~mm}$. Sebanyak 200 gram sekam yang sudah diayak dicampur dengan resin yucallac 157 (1\% katalis mekpo dari berat resin) sebanyak 30\%, 40\%, 50\%, 60\%, 70\% dan 80\% dari berat sekam dan diaduk merata lalu dituangkan ke dalam cetakan dengan diberi tekanan hingga padat. 
Sampel berupa campuran sekam padi dan resin yang sudah padat kemudian dijemur sampai kering minimal selama 24 jam. Setelah kering sampel dikeluarkan dari cetakan dan dilanjutkan ke pengujian kuat tekan dan kuat lentur.

Kuat tekan papan sekam padi diuji dengan cara ditekan sampai menyebabkan keretakan. Pengujian kuat tekan ini dilakukan untuk mengetahui kuat tekan hancur dari papan sekam padi. Kuat tekan ini mengacu pada standar pengujian ASTM C 109. Nilai kuat tekan papan sekam padi dihitung dengan persamaan (1):

$$
\sigma=\frac{F}{A}
$$

dengan $A$ adalah luas penampang atau permukaan yang diberi gaya $\left(\mathrm{m}^{2}\right), F$ adalah gaya yang diberikan $(\mathrm{N})$ dan $\sigma$ adalah kuat tekan $\left(\mathrm{N} / \mathrm{m}^{2}\right)$.

Kekuatan lentur atau kekuatan bending adalah tegangan bending terbesar yang dapat diterima akibat pembebanan luar tanpa mengalami deformasi besar. Pengujian kuat lentur dilakukan untuk mengetahui ketahanan suatu bahan terhadap pembebanan pada titik lentur dan juga untuk mengetahui keelastisan suatu bahan. Cara pengujian kuat lentur ini dengan memberikan pembebanan tegak lurus terhadap sampel dengan tiga titik lentur dan titik-titik sebagai penahan yang berjarak tertentu. Titik pembebanan diletakkan pada pertengahan panjang sampel. Pada pengujian ini terjadi perlengkungan pada titik tengah sampel dan besarnya perlengkungan ini dinamakan defleksi $(\delta)$. Beban maksimum (W maks) dan regangan saat spesimen patah kemudian dicatat.

Pada perhitungan untuk menentukan kekuatan lentur, digunakan persamaan (2) sesuai standar ASTM D-790, yaitu :

$$
K=\frac{3 W l}{2 b h^{2}}
$$

dengan $K$ adalah kuat lentur sampel $\left(\mathrm{N} / \mathrm{m}^{2}\right), W$ adalah beban patah maksimum $(\mathrm{kN}), l$ adalah jarak tumpuan $(\mathrm{cm}), b$ adalah lebar rata - rata sampel $(\mathrm{cm})$ dan $h$ adalah tebal rata-rata sampel $(\mathrm{cm})$.

\section{HASIL DAN PEMBAHASAN}

\section{Kuat Tekan}

Hasil pengujian kuat tekan papan partikel sekam padi dengan variasi resin dapat dilihat pada Tabel 1 dan grafik hubungan variasi resin dengan kuat tekan dapat dilihat pada Gambar 1.

Tabel 1. Hasil perhitungan kuat tekan

\begin{tabular}{|c|c|c|c|c|c|}
\hline No. & Variasi Resin & $\begin{array}{c}\text { Panjang } \\
\text { Sampel }(\mathrm{cm})\end{array}$ & $\begin{array}{c}\text { Lebar Sampel } \\
(\mathrm{cm})\end{array}$ & $\begin{array}{c}\text { Beban } \\
(\mathrm{kN})\end{array}$ & $\begin{array}{c}\text { Kuat Tekan } \\
\left(\mathrm{N} / \mathrm{m}^{2}\right)\end{array}$ \\
\hline 1 & $30 \%$ & 3 & 5 & 11 & $7,3 \times 10^{6}$ \\
\hline 2 & $40 \%$ & 3 & 5 & 45 & $3,0 \times 10^{7}$ \\
\hline 3 & $50 \%$ & 3 & 5 & 82 & $5,5 \times 10^{7}$ \\
\hline 4 & $60 \%$ & 3 & 5 & 94 & $6,3 \times 10^{7}$ \\
\hline 5 & $70 \%$ & 3 & 5 & 104 & $6,9 \times 10^{7}$ \\
\hline 6 & $80 \%$ & 3 & 5 & 138 & $9,2 \times 10^{7}$ \\
\hline
\end{tabular}


Papan partikel sekam padi yang dihasilkan pada penelitian ini memiliki nilai kuat tekan pada kisaran $7,3 \times 10^{6} \mathrm{~N} / \mathrm{m}^{2}-9,2 \times 10^{7} \mathrm{~N} / \mathrm{m}^{2}$. Nilai kuat tekan papan partikel sekam padi yang diperoleh meningkat sesuai dengan proporsi penambahan jumlah resin. Nilai kuat tekan maksimum diperoleh pada komposisi resin $80 \%$ yaitu $9,2 \times 10^{7} \mathrm{~N} / \mathrm{m}^{2}$ dan nilai minimum diperoleh pada komposisi resin $30 \%$ yaitu $7,3 \times 10^{6} \mathrm{~N} / \mathrm{m}^{2}$.

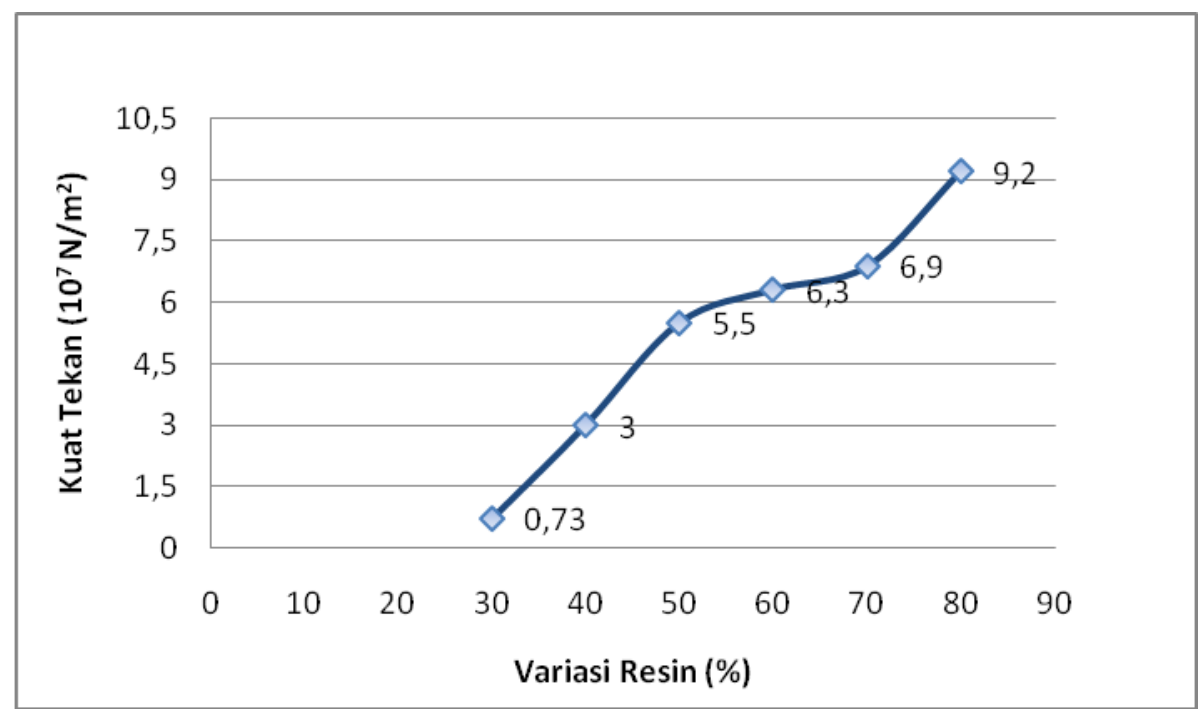

Gambar 1 Grafik hubungan kuat tekan papan partikel sekam padi terhadap variasi resin

Gambar 1 menunjukkan bahwa papan partikel sekam padi dengan komposisi resin $30 \%$ memiliki nilai kuat tekan terendah yaitu $7,3 \times 10^{6} \mathrm{~N} / \mathrm{m}^{2}$. Hal ini disebabkan karena sekam padi yang digunakan lebih besar dari jumlah resin sehingga menyebabkan resin tidak mampu untuk mengikat serat, akibatnya terbentuk kekosongan pada sampel sehingga menurunkan nilai kuat tekan.

Pada papan partikel sekam padi dengan kadar resin $40 \%$ diperoleh nilai kuat tekan sebesar $3 \times 10^{7} \mathrm{~N} / \mathrm{m}^{2}$. Pada papan partikel yang kedua ini, nilai kuat tekannya lebih tinggi dari nilai kuat tekan papan partikel dengan kadar resin $30 \%$ karena kemampuan resin untuk mengikat sekam padi pada papan partikel ini lebih kuat.

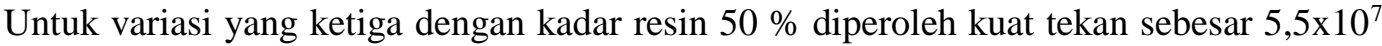
$\mathrm{N} / \mathrm{m}^{2}$. Papan partikel ini memiliki nilai kuat tekan lebih tingi dari papan partikel dengan kadar resin $30 \%$ dan $40 \%$. Hal ini disebabkan karena resin dapat mengikat sekam padi dengan baik dimana perbandingan resin dan sekamnya sama. Sehingga, kuat tekan papan partikel yang dihasilkan lebih tinggi.

Pada variasi resin $60 \%$ nilai kuat tekan papan partikel sekam padi sebesar $6,3 \times 10^{7} \mathrm{~N} / \mathrm{m}^{2}$. Papan partikel ini memiliki nilai kuat tekan yang lebih tinggi dari papan partikel yang variasi resinnya $30 \%, 40 \%$ dan $50 \%$. Pada papan partikel ini resinnya lebih dominan dari sekam, sehingga kuat tekan papan partikel yang dihasilkan juga lebih tinggi karena resin polyester sendiri sudah memiliki kuat tekan yang tinggi.

Papan partikel dengan variasi resin $70 \%$ dan $80 \%$ memiliki nilai kuat tekan berturut turut sebesar $6,9 \times 10^{7} \mathrm{~N} / \mathrm{m}^{2}$ dan $9,2 \times 10^{7} \mathrm{~N} / \mathrm{m}^{2}$. Pada variasi ini komposisi resin lebih banyak dari sekam, sehingga terbentuk ikatan yang kuat antara matriks dan serat sehingga kuat tekan sampel lebih tinggi daripada komposisi yang lain. Nilai kuat tekan papan partikel ini banyak dipengaruhi oleh resin.

Dari penelitian ini, variasi resin mempengaruhi nilai kuat tekan papan partikel sekam padi, dimana semakin banyak jumlah resin menyebabkan kontak antar partikel semakin 
baik sehingga ikatan antar partikel juga semakin baik dan semakin kuat serta papan partikel yang dihasilkan menjadi semakin stabil (Surdia, 2000).

\section{Kuat Lentur}

Hasil p engujian terhadap kuat lentur papan partikel sekam padi dengan variasi resin berturut - turut sebanyak $30 \%, 40 \%, 50 \%, 60 \%, 70 \%$, dan $80 \%$ dengan menggunakan alat kuat tekan jenis Wekob 2153 Neu Wulmshorf diperoleh hasil seperti pada Tabel 2. Grafik hubungan variasi resin dengan kuat lentur dapat dilihat pada Gambar 2.

Tabel 2 Hasil perhitungan kuat lentur

\begin{tabular}{|c|c|c|c|c|c|c|}
\hline No. & $\begin{array}{l}\text { Variasi } \\
\text { Resin }\end{array}$ & $\begin{array}{c}\text { Panjang } \\
\text { Sampel } \\
(\mathrm{cm})\end{array}$ & $\begin{array}{c}\text { Lebar } \\
\text { Sampel } \\
(\mathrm{cm})\end{array}$ & $\begin{array}{c}\text { Tinggi } \\
\text { Sampel } \\
(\mathrm{cm})\end{array}$ & $\begin{array}{c}\text { Beban } \\
(\mathrm{kN})\end{array}$ & $\begin{array}{l}\text { Kuat Lentur } \\
\qquad\left(\mathrm{N} / \mathrm{m}^{2}\right)\end{array}$ \\
\hline 1. & $30 \%$ & 10 & 3 & 1,2 & 0,5 & $1,3 \times 10^{7}$ \\
\hline 2. & $40 \%$ & 10 & 3 & 1,4 & 0,85 & $1,7 \times 10^{7}$ \\
\hline 3. & $50 \%$ & 10 & 3 & 1,5 & 2,25 & $4 \times 10^{7}$ \\
\hline 4. & $60 \%$ & 10 & 3 & 2 & 3,5 & $3,5 \times 10^{7}$ \\
\hline 5. & $70 \%$ & 10 & 3 & 2,2 & 2,4 & $2 \times 10^{7}$ \\
\hline 6. & $80 \%$ & 10 & 3 & 2,5 & 3,65 & $2,34 \times 10^{7}$ \\
\hline
\end{tabular}

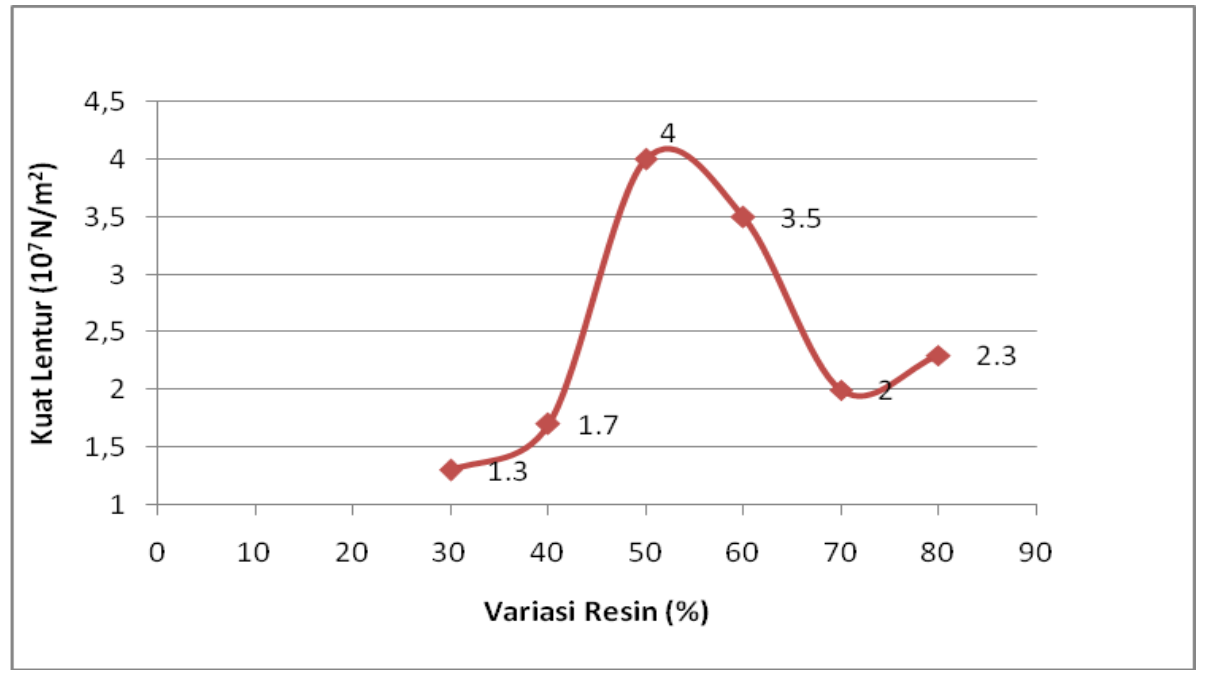

Gambar 2. Grafik hubungan kuat lentur papan partikel sekam padi terhadap variasi resin

Papan partikel sekam padi yang dihasilkan pada penelitian ini memiliki nilai kuat lentur antara $1,3 \times 10^{7} \mathrm{~N} / \mathrm{m}^{2}-4 \times 10^{7} \mathrm{~N} / \mathrm{m}^{2}$. Dari Gambar 2 terlihat bahwa pada variasi resin $30 \%$ memiliki nilai kuat lentur sebesar $1,3 \times 10^{7} \mathrm{~N} / \mathrm{m}^{2}$. Hal ini, disebabkan karena komposisi resin yang digunakan lebih kecil dibandingkan dengan sekam padi, sehingga resin tidak dapat mengikat sekam padi dengan baik, akibatnya nilai kuat lentur yang dihasilkan rendah.

Papan partikel yang kedua dengan kadar resin $40 \%$ mempunyai nilai kuat lentur sebesar $1,7 \times 10^{7} \mathrm{~N} / \mathrm{m}^{2}$. Pada benda uji yang kedua ini, jumlah resinnya bertambah dan 
kemampuan resin mengikat sekam padi juga semakin besar sehingga nilai kuat lenturnya lebih tinggi dari nilai kuat lentur benda uji yang pertama.

Untuk variasi yang ketiga dengan kadar resin $50 \%$ diperoleh kuat lentur sebesar $4 \times 10^{7}$ $\mathrm{N} / \mathrm{m}^{2}$. Benda uji ini memiliki nilai kuat lentur paling tinggi di antara benda uji yang lain. Hal ini disebabkan karena dengan komposisi resin dan sekam padi yang sama, resin dapat mengikat sekam padi dengan baik sehingga kuat lenturnya juga semakin baik.

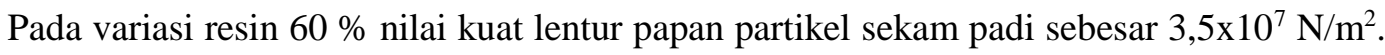
Pada benda uji ini mengalami penurunan nilai kuat tekan dari pada benda uji yang variasi resinnya $50 \%$. Hal ini, diduga karena pada saat pengadukan sampel tidak homogen dan pencetakan papan partikel yang kurang padat. Sehingga, terbentuk void, yaitu adanya celah pada serat atau bentuk serat yang kurang sempurna yang dapat menyebabkan matrik tidak mampu mengisi ruang kosong pada cetakan. Bila papan partikel tersebut menerima beban, maka daerah tegangan akan berpindah ke daerah void sehingga akan mengurangi kekuatan papan partikel tersebut. Pada pengujian lentur akan berakibat lolosnya serat dari matrik.

Variasi resin $70 \%$ dan $80 \%$ memiliki nilai kuat lentur berturut - turut sebesar $2 \times 10^{7}$ $\mathrm{N} / \mathrm{m}^{2}$ dan $2,3 \times 10^{7} \mathrm{~N} / \mathrm{m}^{2}$. Pada variasi resin $70 \%$ mengalami penurunan nilai kuat lentur dari papan partikel sekam padi dengan kadar resin $60 \%$. Hal ini diduga juga akibat adanya void pada papan partikel akibat pengadukan yang tidak homogen. Selain itu nilai kuat lentur papan partikel juga sangat dipengaruhi oleh kuat lentur resin polyester yang besarnya sekitar $2,88 \times 10^{7} \mathrm{~N} / \mathrm{m}^{2}$. Dengan komposisi resin yang lebih besar dari sekam padi, diduga nilai kuat lentur papan partikel juga mendekati nilai kuat lentur resin yang digunakan.

\section{KESIMPULAN}

Dari hasil pengujian kuat tekan dan kuat lentur papan partikel sekam padi dengan variasi komposisi resin dapat disimpulkan bahwa papan partikel sekam padi yang memiliki nilai kuat tekan maksimum yaitu pada variasi resin $80 \%$ sebesar $9,2 \times 10^{7} \mathrm{~N} / \mathrm{m}^{2}$ dan nilai kuat tekan minimum pada variasi resin $30 \%$ sebesar $7,3 \times 10^{6} \mathrm{~N} / \mathrm{m}^{2}$. Nilai kuat lentur maksimum didapatkan pada variasi resin $50 \%$ yaitu sebesar $4 \times 10^{7} \mathrm{~N} / \mathrm{m}^{2}$ dan nilai minimum pada variasi resin $30 \%$ sebesar $1,3 \times 10^{7} \mathrm{~N} / \mathrm{m}^{2}$.

\section{DAFTAR PUSTAKA}

1. Adibrata, S, 2001, Pemanfaatan Sekam Padi Dan Sabut Kelapa Sebagai Bahan Pembuatan Papan Partikel, Jurusan Teknologi Industri Pertanian, IPB Bogor

2. Appanah, S. and Turnbull J. M., 1998, A Review of Diptecocarps : Taxonomy, Ecology and silviculture Centre for international foresty Research, Bogor

3. Arbintarso, S dkk, 2008, Modulus Elastisitas dan Modulus Pecah Papan Partikel Sekam Padi, Jurnal Teknologi Technoscientia ISSN: 1979-8415 Vol. 1 No. 1 Agustus 2008

4. Govindarao, V. M. H., 1980, Utilization of Rice Husk - A Preliminary Analysis, Journal ci. Ind. Res. 39 (9), 495.

5. Murdiyono, S, 2009, Studi Perlakuan Alkali Terhadap Kekuatan Impak dan Bending Komposit Serat Rami Bermatrik Polyester dengan Core Sekam Padi Bermatrik Urea Formaldehide, Makalah Pribadi, Universitas Muhammadiyah Surakarta.

6. Nuryono dan Narsito, 2003, Sintesis Sluka Gel Terenkapsulasi Enzim dari Abu Sekam Padi dan Aplikasinya untuk Bio Sensor, Jurnal Ilmu Dasar, Universitas Gajah Mada. 